\title{
Performance of Different Varieties of Cauliflower (Brassica Oleracea Var. Botrytis) Under Different Levels of Phosphorus Application in Pot Culture at Lamjung, Nepal
}

\author{
TR Paudel ${ }^{1}$, RK Shrestha ${ }^{1,2 *}$ and A Khanal ${ }^{1}$ \\ ${ }^{1}$ Institute of Agriculture and Animal Science, Lamjung Campus, Nepal \\ ${ }^{2}$ College of Resource and Environment, Southwest University, Chongqing, China
}

${ }^{*}$ Corresponding author: RK Shrestha, College of Resource and Environment, Southwest University, Chongqing, China.

Received Date: October 21, 2019

Published Date: October 29, 2019

\begin{abstract}
The objective of the current review is to review and identify the research gap on the effect of different growth media on rooting percentage, roots and shoot growth performance of grape cutting. Factors affecting rooting of grape cuttings can be internal or external factors. Internal factors affecting rooting of cuttings include the amount of stored food in cuttings, the age and maturity of tissue, the formation of callus and adventitious roots and the presence of leaves and buds on cuttings. The external factors include rooting media, chemical and hormone treatments, light, temperature, mechanical treatment and mist spray. Rooting media is one of the most important factors for rooted cutting production especially in grape. It is one of the factors affecting rooting and growth of grape cuttings. Types of media have significantly influenced the rooting and vegetative growth of cuttings. Different planting media have significantly influenced the vegetative growth of cuttings; due to the level of organic matter content, water holding difference. The suitability of the rooting medium depends on the species, type of cuttings, growing conditions, season of the year and the cost effectiveness of the medium components. A media which is light, rich, porous, well drained and free from pathogens is considered ideal for growing of grape. A good potting medium must be easy to supply, process and a cheap source. Choosing the most suitable growing media for the achievement of a successful plant production is very important Inadequate soil available Phosphorus (P) is principle limiting factor of cauliflower productivity in Nepal, and judicious P fertilizer management is one of the best strategies to increase the yield of cauliflower. A pot experiment was conducted at Lamjung Campus during October, 2018 to February, 2019 to We investigated the effect of five levels of soil application of $\mathrm{P}\left(0 \mathrm{~kg} \mathrm{ha}{ }^{-1}, 100 \mathrm{kgha}\right.$ ${ }^{1}, 120 \mathrm{~kg} \mathrm{ha}^{-1}, 140 \mathrm{~kg} \mathrm{ha}^{-1}$ and $160 \mathrm{~kg} \mathrm{ha}^{-1}$ ) on growth and yield attributes of two cauliflower varieties (Kathmandu Local and Snow Grace) with a pot experiment. Hence, the experimental design was two factorial complete randomized designs (CRD) with four replications. The result revealed that the soil application of P showed significant effect on all growth and yield attributes of cauliflower cultivars.

It was found that maximum plant height (28.18), days to curd initiation (76.12), number of leaves (18.38), root length (28.76), curd weight $(0.750 \mathrm{~kg})$ and yield ha-1 $\left(27.54\right.$ tons) were recorded and Snow grace expressed highest curd weight $\left(0.83 \mathrm{~kg}^{-1}\right.$ plant $\left.{ }^{-1}\right)$ and highest yield (31.07ton ha ${ }^{1}$ ) at P level of $160 \mathrm{~kg} \mathrm{ha}^{-1}$ as compared to other levels of P. Varieties and P level interacted significantly for plant height, curd weight and curd yield. It was concluded that application of phosphorus $\left(160 \mathrm{~kg} \mathrm{ha}^{-1}\right)$ and cultivar Snow grace can produce highest yield and also further research is needed to optimize the $\mathrm{P}$ rate for enhancing yield.
\end{abstract}

Keywords: Cauliflower; Curd initiation; Curd yield; Phosphorus; Variety

\section{Introduction}

Phosphorus is one of the major macro essential nutrient that is occurred in most of the plant in concentration by dry weight of $0.1-0.5$ percent and in most mineral soils in concentration of 0.002-0.5 percent with average of 0.05 percent and absorb $P$ in the form of either $\mathrm{H}_{2} \mathrm{PO}_{4}^{-}$or as orthophosphate ion $\mathrm{HPO}_{4}^{2-}$ depending on soil pH [1]. The growth and development of cauliflower is directly influenced by the application of phosphorus as the phosphorus involves the physiological activities of cauliflower. $\mathrm{P}$ is the key element in many physiological [2] and biochemical process although it is absorbed in small amounts by plants $[3,4]$ and least mobile and available to plants in most soil conditions [5].

Phosphorus is the principal yield limiting factor for cauliflower production [6] and major abiotic stress that inhibits plant growth and crop productivity on $30-40 \%$ of the world's arable land [7] 
and deficient on $41.73 \%$ of total cultivated land (28\%) of Nepal (MOAD, 2072). Most of the Nepalese farmers use the chemical fertilizers haphazardly and blindly without conscious about the negative impact to the soil, health and environment because of insufficient knowledge about judiciously, rationally, efficiently and site- specific use chemical fertilizer that causes the decreased the crop productivity and soil fertility in Nepal. Insufficient research on balanced fertilizer recommendation and poor selection of cauliflower cultivars is major challenge of commercialization and competitiveness production of cauliflower in Nepal. Judicious and balance use of $\mathrm{P}$ fertilizer as well as site specific $\mathrm{P}$ fertilizer management is one of the best alternative strategies to increase the production per unit limited area of production and it is hypothesized that addition of $\mathrm{P}$ in the soil would have significant contribute on cauliflower production.

\section{Materials and Methods}

This experiment was carried out at Sundarbazar municipality of Lamjung districts from October 2018 to February 2019 to assess the effect of soil P input on yield and yield attributes in cauliflower varieties. Soil was collected from horticulture farm of IAAS, Lamjung Campus and was analyzed for total nitrogen, available phosphorus, available potassium, organic matter and soil $\mathrm{P}^{\mathrm{H}}$ (Table 1 ).

Table 1: Chemical properties of sampled soil.

\begin{tabular}{|c|c|c|}
\hline Parameter & Value & Remarks \\
\hline Soil available $\mathrm{pH}$ & 5.8 & Acidic \\
\hline Soil available organic matter $\left(\mathrm{ton} \mathrm{ha}^{-1}\right)$ & 1.642 & Low \\
\hline Soil available Nitrogen & $0.08 \%$ & Low \\
\hline Soil available Phosphorus $\left(\mathrm{kg} \mathrm{ha}^{-1}\right)$ & 7.75 & Very low \\
\hline Soil available Potassium $\left(\mathrm{kg} \mathrm{ha}^{-1}\right)$ & 536.26 & High \\
\hline Soil available Boron $(\mu \mathrm{g} / \mathrm{g})$ & 1.8 & Medium \\
\hline
\end{tabular}

Then, we undertook two factorial experiments- levels of phosphorus inputs and cauliflowers as factors. Two commonly grown varieties of cauliflower (Kathmandu Local and Snow Grace) were purch. We mixed the air-dried soils with air dried farmyard manure ( $0.5 \mathrm{~kg}$ FYM $/ \mathrm{kg}$ Soil) and filled in polypot ( $4 \mathrm{~kg}$ soil $/$ pot). In each pot, N, K, B and Mo were applied at the rate 11.73gm ,3.6gm, $0.49 \mathrm{gm}$ and $5.12 \mathrm{mg}$ respectively and also the source of nutrient like urea, potassium chloride, Borax, sodium molybdate. Then after, we applied five levels of the $\mathrm{P}$ with air dried soils in $0.00215 \mathrm{~m}^{3}$ sized pots and applied five levels of $\mathrm{P}\left(0 \mathrm{kgha}^{-1}, 80 \mathrm{kgha}^{-1}, 120 \mathrm{kgha}^{-}\right.$ ${ }^{1}, 140 \mathrm{kgha}^{-1}, 160 \mathrm{kgha}^{-1}$ ) using Single super phosphate. Then after we transplanted $29 \mathrm{~d}$ old seedling of cauliflower in the pot and arranged the pots in completely randomized designed with four repetition. Nitrogen was top dressed at the rate of $2.93 \mathrm{gm}$ in $30 \mathrm{~d}$ and $60 \mathrm{~d}$ after transplanting. Soil was kept at $0.65 \%$ field capacity during the entire growing period. Before harvesting the plants at physiological maturity-appearance of white head- Plant height, leaves numbers, days for days required for the curd initiation and physiological maturity were recorded was measured. After harvesting, root length and curd yield were measured.

The mean separation was carried out with ANOVA using package SPSS software version 24 edition and graphs were developed using Origin 8 Software. The data recorded was statistically analyzed according to Complete Block Design (CRD)with double factor using a statistical.

\section{Results and Discussion \\ Plant height}

The data regarding the plant height are shown in Table (2) depicted that Phosphorus level $(\mathrm{P}<0.01)$ and cauliflower varieties $(P<0.01)$ are statistically different and interaction between them also found significantly different $(\mathrm{P}<0.01)$.

Table 2: Effect of different levels of phosphorus and varieties on cauliflower varieties no. of leaves, plant height, days to curd initiation, days to harvest, root length, curd weight and curd yield.

\begin{tabular}{|c|c|c|c|c|c|c|c|}
\hline P level (kgha-1) & $\begin{array}{l}\text { Mean No. } \\
\text { of leaves }\end{array}$ & $\begin{array}{l}\text { Mean Plant } \\
\text { Height }(\mathrm{cm})\end{array}$ & $\begin{array}{l}\text { Mean Days to Curd } \\
\text { Initiation (Days) }\end{array}$ & $\begin{array}{l}\text { Mean Days to } \\
\text { Harvest (Days) }\end{array}$ & $\begin{array}{l}\text { Mean Root } \\
\text { length }(\mathrm{cm})\end{array}$ & $\begin{array}{l}\text { Mean Curd } \\
\text { Weight (Kg) }\end{array}$ & $\begin{array}{l}\text { Mean Curd Yield } \\
\text { (tons ha-1) }\end{array}$ \\
\hline 0 & $8.88 \mathrm{~d}$ & $12.64 d$ & $93.50 \mathrm{~d}$ & $122.2 \mathrm{~d}$ & $12.54 \mathrm{~d}$ & $0.171 \mathrm{e}$ & $3.01 \mathrm{e}$ \\
\hline 100 & $12.88 \mathrm{c}$ & $17.38 \mathrm{c}$ & $88.12 \mathrm{c}$ & $116.8 \mathrm{c}$ & $18.50 \mathrm{c}$ & $0.38 \mathrm{~d}$ & $14.24 \mathrm{~d}$ \\
\hline 120 & $15.62 b$ & $22.51 b$ & $86.62 \mathrm{bc}$ & $112.8 b$ & $19.14 \mathrm{c}$ & $0.52 \mathrm{c}$ & $19.14 \mathrm{c}$ \\
\hline 140 & $16.38 b$ & $22.57 \mathrm{~b}$ & $85.0 \mathrm{~b}$ & $112.2 \mathrm{~b}$ & $23.93 b$ & $0.59 \mathrm{~b}$ & $21.88 \mathrm{~b}$ \\
\hline 160 & $18.38 \mathrm{a}$ & $28.18 a$ & $76.12 \mathrm{a}$ & $107.2 \mathrm{a}$ & $28.75 a$ & $0.75 a$ & $27.54 \mathrm{a}$ \\
\hline F-test & $* *$ & $* *$ & $* *$ & $* *$ & $* *$ & $* *$ & $* *$ \\
\hline $\operatorname{SEm}( \pm)$ & 0.412 & 0.527 & 0.587 & 0.506 & 0.472 & 0.008 & 0.33 \\
\hline LSD & 1.19 & 1.523 & 1.696 & 1.462 & 1.363 & 0.024 & 0.95 \\
\hline C.V.\% & 8.1 & 7.2 & 1.9 & 1.3 & 6.5 & 4.9 & 5.5 \\
\hline \multicolumn{8}{|l|}{ Variety } \\
\hline $\begin{array}{l}\text { Kathmand u } \\
\text { local }\end{array}$ & 13.3 & 23.57 & 90.55 & 120.35 & 22.7 & 0.43 & 14.88 \\
\hline Snow & 15.35 & 17.73 & 81.2 & 107.95 & 18.45 & 0.53 & 19.45 \\
\hline \multicolumn{8}{|l|}{ grace } \\
\hline F-test & $* *$ & $* *$ & $* *$ & $* *$ & $* *$ & $* *$ & $* *$ \\
\hline $\operatorname{SEm}( \pm)$ & 0.26 & 0.33 & 0.37 & 0.32 & 0.29 & 0.005 & 0.27 \\
\hline
\end{tabular}




\begin{tabular}{|c|c|c|c|c|c|c|c|}
\hline LSD & 0.75 & 0.96 & 1.07 & 0.92 & 0.86 & 0.015 & 0.6 \\
\hline P level * Variety & & & & & & & \\
\hline Grand Mean & 14.43 & 20.65 & 85.88 & 114.25 & 20.57 & 0.46 & 17.16 \\
\hline SEm ( \pm ) & 0.583 & 0.746 & 0.83 & 0.716 & 0.667 & 0.011 & 0.469 \\
\hline LSD & 1.683 & 2.154 & 2.398 & 2.068 & 1.928 & 0.032 & 1.354 \\
\hline F-test & NS & $* *$ & NS & NS & NS & $* *$ & $*$ \\
\hline
\end{tabular}

Similar letter in upper case are statistically non-significant (NS) at $1 \%\left(^{* *}\right)$ and $5 \%\left(^{*}\right)$ level of significance.

Cauliflower varieties showed significant difference at different level of phosphorus application. Cauliflower varieties showed maximum values of plant height $(28.18 \mathrm{~cm})$ when $160 \mathrm{kgha}^{-1}$ of $\mathrm{P}$ was applied and low value of plant height $(12.64 \mathrm{~cm})$ for control treatment plants. The plant height at $160 \mathrm{kgha}^{-1}$ was significantly different with recommended dose of P. i.e. $120 \mathrm{kgha}^{-1}(22.51 \mathrm{~cm})$ which was statistically non-significant with plant height at 140 kgha $^{-1}(22.57 \mathrm{~cm})$.

Variety Kathmandu Local expressed maximum value of plant height $(23.57 \mathrm{~cm})$ and minimum value of plant height $(17.73 \mathrm{~cm})$ was expressed by Snow Grace. The result showed that plant height is increased with increases P level. This might be due to its vital role in root development and nutrient absorption that increase plant growth and ultimately influence plant height. These results could be due to the synergistic effect of $\mathrm{P}$ with $\mathrm{N}$ that helped the efficiency of nitrogen uptake, which enhanced vegetative growth of broccoli plants [8]. Sharma et al., [9], Singh [10] and Reddy et al., [8] found the same trend of the present investigation of research. The plant height is directly influenced by cauliflower varieties which might be due to its genotypic governing varietal characters on plant height and also depend on whether plant is taller or dwarf variety. The effect on plant height by interaction between $P$ level and varieties are significant which might be due to highly genetic response and high nutrient use efficiency of one variety that other variety.

\section{Number of leaves}

The data regarding the number of leaves are shown in Table (2) interpreted that Phosphorus level $(\mathrm{P}<0.01)$ and cauliflower varieties $(\mathrm{P}<0.01)$ are statistically different but interaction between them found non-significantly different $(\mathrm{P}=0.990)$. Cauliflower varieties showed significant difference at different level of phosphorus application. The maximum numbers of leaves per plant (18.38) were obtained at $160 \mathrm{~kg} P$ ha- 1 and minimum number of leaves per plant (8.88) in without application of P. The variety Snow grace had a greater number of leaves per plant (15.35) which was significantly superior over Kathmandu local variety (13.50). The increased number of leaves per plant with increased level of $\mathrm{P}$ might be due to being major macro nutrient which play vital role in photosynthesis, energy storage, cell division and cell enlargement that helps in enhancement of number of leaves [11]. Randhawa and Bhail [12] reported that higher dose of $P$ gave positive response in increasing the numbers of leaves. Similarly, Elahi et al., [13] and Uddain [11] found that phosphorus had significantly influenced the number of leaves per plant of cauliflower. The number of leaves per plant varied with varieties due to their own genetic makeup which is linked with inters nodal length [13]. The interaction of $P$ level and varieties had not affected on number of leaves per plant that might be due to their effect on number of leaves independently and genotype of two varieties almost similar response to different P level.

\section{Days to curd initiation}

The effect of different level of phosphorus on days to curd initiation of different varieties showed Table (2) that expressed the cauliflower varieties $(\mathrm{P}<0.01)$ and Phosphorus level $(\mathrm{P}<0.01)$ were statistically significant but their interaction between them were statistically insignificant $(\mathrm{P}=0.089)$. The minimum days to curd initiation (76.12days) obtained at application of $160 \mathrm{~kg} \mathrm{P}$ ha $^{-1}$ and maximum days to curd initiation (93.50days) at control treated plants. The application of P level i.e. $100 \mathrm{kgha}^{-1}, 120 \mathrm{kgha}^{-}$ ${ }^{1}$ and $140 \mathrm{kgha}^{-1}$ had statistically almost similar effect on days to curd initiation of cauliflower varieties. Snow grace varieties had minimum days to curd initiation (81.20 days) which is significantly superior over the Kathmandu local variety (90.55 days). The days to curd initiation decreased with the increased phosphorus level significantly that might be due to its involvement in shorter the vegetative growth period and forced the plants to reach the reproductive stage relatively earlier than other nutrients by increasing metabolic activities in the plan system and involvement in promotion of flower primordial formation earlier. Elahi et al. [13] and Islam et al. [14] found that phosphorus had significant effect in the days required to curd initiation and improved flower formation, fruiting and curd ignition. Similarly, Katiyar [15] and Mitra et al. [16] found that application of phosphorus hastened the crop to reach reproductive stage which is an agreement with the finding of present work. The days to curd initiation was significantly influenced by cauliflower varieties that might be due to the internal genotypic characteristic of varieties that directly determine the period required to curd initiation. The reasons behind this might be days to curd initiation depend on whether the plant is short duration or long duration varieties [17]. Some varieties produce certain chemical signaling that enhance metabolic activities of plant and enhance flowering earlier than other. Saini [18] reported that period for curd initiations were differed among varieties due to the genetic characteristics of the cultivars. The interaction of cauliflower varieties and P level had similar effect on days to curd initiation that might be the genetic responses of two varieties almost similar to the different level of phosphorus on days to curd initiation which is similar result with $[13,14]$. 


\section{Root length}

The effect of phosphorus level on root length of cauliflower varieties is shown in Table (2) depicted that phosphorus level $(\mathrm{P}<0.01)$ and cauliflower varieties $(\mathrm{P}<0.01)$ are statistically significant but interaction between them are insignificant $(\mathrm{P}=0.677)$. The cauliflower varieties showed maximum root length $(28.76 \mathrm{~cm})$ with application of $160 \mathrm{~kg} \mathrm{P} \mathrm{ha}^{-1}$ and minimum root length $(12.54 \mathrm{~cm})$ at control treated plants. The application of P level i.e. $100 \mathrm{kgha}^{-1}$ and $120 \mathrm{kgha}^{-1}$ had statistically almost similar effect on days to harvest of cauliflower varieties. Kathmandu Local had maximum root length $(22.70 \mathrm{~cm})$ which is significantly superior over the Snow Grace variety $(18.45 \mathrm{~cm})$. The result of the study revealed that increased $P$ level increases root length that might be due to its involvement in promotion of physiological processes in the plant system which leads to increase the root growth that ultimately helps in stimulation of root length in plants. The application of $\mathrm{P}$ stimulates cell division in the meristematic region and lead to higher concentration of bioactive gibberellins (GA) that may promote the root growth. Kim et al. [19] stated that increasing P supply increased root growth. Uddain [11] found that Phosphorus exhibited a significant influence on root length of broccoli plants. Kumar et al. [20] found the same trend of the present investigation. The root length was significantly influenced by cauliflower varieties that might be due to the varietal characteristics governing by internal genotypic characteristic of varieties. However, Snow grace having higher yield having minimum root length which might be due to higher Mycorrhizal association in Snow grace [17].

\section{Curd weight}

The data regarding the curd weight are shown in Table (2) interpreted that Phosphorus level $(\mathrm{P}<0.01)$ and cauliflowervarieties $(\mathrm{P}<0.01)$ are statistically different as well as interaction between them found significantly different $(\mathrm{P}=0.002)$. The cauliflower varieties showed maximum mean curd weight $(0.750 \mathrm{~kg})$ with application of $160 \mathrm{~kg} \mathrm{P} \mathrm{ha}^{-1}$ which is significantly superior to others P levels as well as and as over control treated plant $(0.0814 \mathrm{~kg})$. Snow grace varieties had high mean curd weight $(0.52 \mathrm{~kg})$ which is significantly superior over the Kathmandu local variety $(0.406 \mathrm{~kg}$ ). These results revealed that increased $P$ level increases curd weight per plant. The reasons behind that its vital role in all physiological and metabolic activities, photosynthesis, cell division and cell enlargement and strongly correlated with all yield attributes. Elahi et al., [13] found that phosphorus had significant influence on curd weight of cultivars and vigorous growths of the plant are correlated with proper nutrition. McPharlin et al., [21] found that phosphorus helps in increment of photosynthesis and proper curd formation. Similarly, Sheppard and Bates [22] reported that yield and chemical composition are related with P level. Randhawa \& Bhail [12] reported that more plant curd weight was seen in the plant which received highest level of phosphorus. Uddain [11] found that Phosphorus exhibited a significant influence on main curd weight of broccoli plants.

Saimbhi et al., [23], Balyan et al., [24] and Singh [10] also found similar trend of results as present research finding. The cultivars highly influenced the curd weight per plant as curd weight is determined by environmental factors as well as genetic factors of cultivars.

\section{Curd yield (ton ha-1)}

The data regarding the curd yield (ton ha ${ }^{-1}$ ) are shown in Table (2) that Phosphorus level $(\mathrm{P}<0.01)$ and cauliflower varieties $(\mathrm{P}<0.01)$ are statistically different as well as interaction between them found significantly different $(\mathrm{P}=0.002)$.

The cauliflower varieties showed maximum mean curd yield (27.54tonha ${ }^{-1}$ ) with application of $160 \mathrm{~kg} \mathrm{P} \mathrm{ha}^{-1}$ which is significantly superior to others $\mathrm{P}$ levels as well as and as over control treated plant (3.01 tonha-1). Snow Grace varieties had high mean curd yield (19.45 tonha ${ }^{-1}$ ) which is significantly superior over the Kathmandu local variety (14.88tonha-1).

The result of this study verified that increased level of P increases the curd yield of cauliflower. This might be due to its significant role in role in photosynthesis, cell division and cell enlargement and strongly correlation with yield attributes. The yield was influenced by the yield containing parameters of the cauliflower which is similar with result reported by [9]. Uddain [11] found that Application of phosphorus exhibited a significant influence on yield per hectare of broccoli plants. Similar pattern of results was found by another scientist like Balyan et al. [24]; Sharma et al. [9]; Singh [10] and Reddy et al. [8]. The cultivars highly influenced the curd yield (ton per hectar) as curd yield is determined by environmental factors as well as genetic factors of cultivars.

\section{Conclusion}

The finding of this research study shows that increased level of $\mathrm{P}$ enhances the growth and yield parameters of cauliflower. Phosphorus (P) application in the soil enhances the number of leaves, hasten reproductive stage and increases curd weight and root length which finally increases the yield [25]. However, varieties response to soil application of P also affect the yield. Snow Grace variety shows more $\mathrm{P}$ use efficiency as it can produce highest yield under P deficient soils at $160 \mathrm{~kg} \mathrm{P} \mathrm{ha}^{-1}$.

Furthermore, research is required for the confirmation of present findings at different location of Lamjung district.

\section{Acknowledgement}

None.

\section{Conflict of Interest}

No conflict of interest.

\section{References}

1. Havlin JL, SL Tisdale, WL Nelson, JD Beaton (2016) Soil fertility and fertilizers. Uttar Pradesh, India, Pearson India Education Services Pvt Ltd, pp. 190-224.

2. Taiz L, Zeiger E (2010) Photosynthesis: the light reactions. Plant physiology 5: 163-198.

3. Castoldi R, HCO Charlo, PF Vargas LT Braz (2009) Crescimento, acúmulo de nutrientes is produtividade da cultura da couve-flor. Horticulture of Brasileira 27: 438- 446. 
4. Marković S, N Čereković, V Todorović, N Kljajić, D Mihajlović (2012) The content of NPK nutrients in vegetative organs of cauliflower (Brassica oleracea var botrytis L) grown in soilless culture technique. Agroznanje 13(4): 633-644.

5. Hinsinger P (2001) Bioavailability of soil inorganic P in the rhizosphere as affected by root- induced chemical changes: a review. Plant and soil 237(2): 173-195.

6. Jaishy SN (2000) Current fertility status of Nepal and IPNS. Component of integrated plant, pp. 63-72.

7. Von Uexkull, H. R., and E. Mutert. (1995). Global extent, development and economic impact of acid soils. Plant and soil. 171(1): 1-15.

8. Reddy AR, G Padmaja (2005) Effect of phosphorus and zinc on curd yield and quality of cauliflower. J Res ANGRAU 33(1): 65-98.

9. Sharma SK, R Sharma, BN Korla (2002) Effect of nitrogen and phosphorus on the growth and seed yield of sprouting broccoli cv. Green head. Hort J 15(2): 87-90.

10. Singh Ak (2004) Effect of nitrogen and phosphorus on growth and curd yield of cauliflower var. snowball -16 under cold arid region of Ladakh, Haryana J Hort Sci 33(1-2): 127-129.

11. Uddain J (2007) Effect of Phosphorus and potassium on growth yield and postharvest assessment of Broccoli (Brassica oleracea var. botrytis L.). Published MSc. Thesis. Sher-e-Bangla Agricultural University, Department of Horticulture cunt Post harvest Technology, Dhaka Bangladesh, pp. 32.

12. Randhawa KS, AS Bhail (1976) Growth, Yield and Quality of Cauliflower (Brassica oleracea var. Botrytis) as influenced by nitrogen, phosphorus and boron. Indian Journal of Horticulture 33(1): 83-91.

13. Elahi E, A Wali, Nasrullah, G Ayub, S Ahmed, Z Huma, N Ahmed (2015) Response of cauliflower (Brassica oleracea L. botrytis) cultivars to phosphorus levels. Pure and Applied Biology 4(2): 187-194.

14. Islam MH, MR Shaheb, S Rahman, AB Ahmed, Islam, PC Sarker (2010) Curd yield and profitability of broccoli as affected by phosphorus and potassium. Int J Sustain Crop Prod 5(2): 1-7.
15. Katiyar D, SM Tripathi, AK Dwivedi, P Vivek (2012) Effect of nitrogen and phosphorus on crop growth, head yield and quality of broccoli (Brassica oleracea L. var. italica). Hort Flora Research Spectrum 1(2): 172-174.

16. Mitra SK, MK Sadhu, TK Bose (1990) Nutrition of Vegetables Crops. Naya Prokash, Calcutta, India, pp. 157-160.

17. Tamang P, RK Shrestha (2018) Effect of Phosphorus Application on Performance of Cauliflower (Brassica oleracea var. botrytis) Varieties. Acta Scientific Agriculture 2(9): 66-68.

18. Saini JP, SR Thakur (1996) Effect of nitrogen and phosphorus on vegetable pea (Pisum sativum) in cold desert area, Indian J Agric Sci 66: 514- 517.

19. Kim HJ, JP Lynch, HM Brown (2008) Ethylene insensitivity impedes a subset of responses to phosphorus deficiency in tomato and Petunia. Plant cell division 31(12): 1744- 1755.

20. Kumar K, KM Goh (1999) Crop residues and management practices: effects on soil quality, soil nitrogen dynamics, crop yield, and nitrogen recovery. In Advances in agronomy 68: 197-319.

21. Mc Pharlin IR, Robertson WJ, Jeffery RC, Weissberg R (2009) Response of cauliflower to phosphate fertilizer placement and soil test phosphorus calibration on a Karra Pkatta sand. Communications in Soil Science and Plant Analysis 26(3-4): 607620.

22. Sheppard SC, TE Bates (1980) Yield and chemical composition of rape in response to nitrogen, phosphorus and potassium. Canadian Journal of Soil Science 60(2): 153-162.

23. Saimbhi MS, K Singh, DS Padda (1969) Influence of nitrogen and phosphorus fertilization on the yield and curd size of cauliflower. Punjab Hort 9: 188-202.

24. Balyan DS, BS Dhankar, DS Rahul, KP Singh (1988) Growth and yield of cauliflower variety, Snowball-16 as influenced by nitrogen, phosphorus and zinc. Haryana J Hort Sci 17(3-4): 247-254.

25. Ministry of Agriculture Development (MOAD) (2016/17) Statistical information on Nepalese Agriculture. Kathmandu, Agri Business Promotion and Statistical Division Agri statistics Section. 